\title{
Importance and Relevance of Gandhian View of Religion and Politics
}

\author{
Dr. V. Indira Devi
}

The problems confronting not only India but the whole world in modern times are tremendous and multidimensional in nature. A sense of despair has not only prevailed over the hope that if men could improve their material conditions this could serve as a stepping stone towards securing values and stable peace. But now it is all too evident that the monumental strides taken in the direction of solving material wants have not been able to lead to fulfillment of intellectual or moral wants, as exemplified in the west.

But one cannot bask in the light of the illusion that moral improvement will follow material progress. What should not also be forgotten is the fact that one of the prime factors, responsible for the fall of the 'Maurya ${ }^{1}$ dynasty was king Ashoka's conversion to Bhuddhism leading to scant attention being paid to army.

No nation can become great or achieve greatness without its people developing a sense of self discipline, social responsibility and willingness to do hard, efficient and cooperative work.

Though the country has made considerable progress in several spheres, still exploitation of a cruel nature in the name of economic theories, caste, religion continueto plague the country.

One of the many such difficulties is the Muslim problem, which is a national problem and not that of a community alone. To refer to Muslims as a minority is a crude simplification of complex problem. Only in terms of the proportion of the total population are they a minority? In terms of their absolute number, which is more than 120 million people they constitute the second largest Muslim - population in the whole world. Within the country, they with respect to absolute numbers, political relevance and socio cultural heritage, are the second dominant segment of the Indian people. ${ }^{1}$

The condition today is such as to demand a pragmatic philosophy which not only meets the present problems,but also goes beyond them, envisaging the future, foreshadowing its patterns, and hence the desparation in mankind today. India needs a philosophy not of renunciation but of active participation.

This suggests that there has been a need for a change that does not truncate itself from the past, neither does it ignore the past but has to be relevant to the present as well as being hopeful for the future. This would meanthat it should be practical/ as any philosophy which is not based on past experiences will be impractical, that it should stress that context and relevance of the social situation without placing the individual and society in confrontation, and that, it should stretch beyond the present with hope and some idealism.

The history of the world shows that numerous philosophies have been tried and tested towards this end, which include doctrines like Facism and Marxism. But surprisingly a concept like Gandhism which has been successsful both in South Africa as well as our independence struggle has been left untouched.

The most important contribution of Gandhi to Indian philosophy, in all likelihood is his emphasis on the experimental habit of mind for resolving the problems of mankind. Gandhi added a new dimension of cooperative participation in social action based on individual freedom and gave new insight into the emerging values without disturbing the social equilibrium. Gandhi always sought to clarify his ideas in action in a pragmatic way. His concern was relating thought and action in the relevant troublesome context and with interpreting truth in terms of consequences.

What is witnessed above all, in the phenomenon of Gandhi, is religion becoming creative in human life. The main purpose of religion is the transformation of human existence from self-centeredness to reality centeredness. Gandhi was real symbol of the feasibility of such a transformation, which is not only uplifting but also challenging and inspirational. He renounced the interests of his ego and became a servant of mankind.

The process was of continuous growth in which his dedication to the service of the higher reality, which he thought of as Truth or God, progressively increased. What is remarkable is that he reached the stage, where one loves God or Truth with all his heart and mind and soul and his neighbors as himself, in the midst of the pressures, disturbances and ambiguities generated by two historic liberation struggles, first in South Africa and then in India, which together a lifetime. ${ }^{2}$

Gandhi as a social reformer and a man of vision preached everything for the benefit of human society. He tried to spiritualise all aspects of human life. He had always in mind the welfare of the entire human race on almost all fronts, be it social or moral or religious or political. 
Gandhi was ignorant of any religion apart from human activity. His religion had humanity as its foundations. He said the service to mankind is service to God. His views were that man should.try to be richer in the virtues of mutual love, understanding and peace and religion helps man in achieving this.

A religion as such does not distinguish caste, creed or sex infect it establishes harmony between religions but it helps dismantle the walls between various faiths. Gandhi did not try to combine the different religions, rather he was more concerned with the governing principles and found truth in all "Personally I think the world as a whole will never have and need not have a single religion".3

To Gandhi the ethical basis of religion meant Karmayoga and Svadharma concepts largely drawn from the Gita and which, according to him, meant fulfilling whatever duties come one's way in the role given to one by God. While living life fully one was to live with a sense of detachment, realising that the spirit was above all the delusions offered by life. In the process of living one always is subjected to opposing forces of good and evil, the battle between them being in the mind and heart. A karma yogi always vanquishes evil and in his heart always good triumphs over it.

Gandhi's views on religion have a great resemblance to the ancient concept of dharma. In ancient India dharma, as also defined in ancient texts like Arthasastra and Manusmriti, constituted a set of moral and ethical values which governed the life of man and at a broader level that of society. As has been pointed out earlier Gandhi also believed that the basic definition of religion was morality, with religion being the practice of morality out its ultimate limits. This religion for him was more than a quest for God, it was a way of life. A way of life with strong mphasis on moral and ethical conduct"..... the morals, ethics and religion are convertible terms. A moral life without reference to religion is like a house built on sand and religion divorced of moral a sounding brass' good only for making a noise and breathing heads. ${ }^{4}$

This concept of dharma as an ethical force was introduced by Gandhi in the nationalist politics. According to him "I think political life must be an echo of private life and that there cannot be any divorce between the two".5 And he was of the opinion ......."Thus it will be seen that for me there is no politics devoid of religion. They subserve religion Political bereft of religion is a death trap because they kill the soul". And at the same time he also warned, "do not mix up religion and ethics. I believe that fundamental ethnics (moral value) is common to all religions". ${ }^{6}$

One thing Gandhi was very clear about was the fact that religion was inseparable from politics. Throughout his long political life he incorporated religion into politics just the way he taught. He could easily visualise the depth to which politics can sink in the absence of a strong moral base.

A religious life is not purified life in isolation, It has social as well as political impact. Religion keep the inherent savagery in human nature within bounds and helps in bringing to the fore the cooperative and sympathatic facets and cleanses the human motive and conduct. Politics is not a game or a gamble to be played and won by politicians. It is a service to the people In this context, it can be said that purified conduct as well as motive and essential for stepping in the political arena. Therefore religion and morality were made the faoundation of politics.

A peaceful and non violent politics rather than power politics can be ensured by religion in politics provided moral vitrues of non-violence, truth and love are truly practiced. His use of nonviolence as a mean of bringing about political change was a unique and path breaking experiment.

".... my religion is dedicated to the service of India through the religion of non violence which I believe to the root of Hinduism. ${ }^{7}$ An integral part of religion for him was to seek truth and only a path of non violence could take one to truth," in order therefore to protest myself against any misunderstanding I have said truth and nonviolence are my creed. ${ }^{8}$

Today we see politics having degenerated to a very sickening state where power hungry politicians fight it out for political power what we are witnessing today is ethical conduct. This is exactly what makes Gandhi's teaching all the more relevant" today the system of Government is devised as to effect every department of our life. It threatens our very existence. If therefore we want to conceive the welfare of the nation we must religiously interest ourselves in the doings of governments and exert a moral influence on them by insisting on them obeying the laws of morality. ${ }^{9}$

For the people of India, religion is too important a part of their lives to be casually set aside, especially so when ancient concept of religion and dharma involving moral and ethical conduct embracess every sphere of life.

But instead of religion being used as a strong binding factor we see religion being used to divide people. Minds are filled with hatred and people are ready to kill each other at the slightest provocation. Trust seems to have evaporated into thin air a small incident is enough to set off devastating riots. All this is in the name of religion.

What should be noted is that far Gandhi mixing religion with politics was not ment in the sense we are witnessing today. It meant for him the infusion of moraland ethical behaviour into politics. Fighting for a place of worship was the last thing he had in his mind when he said religion was inseparable from politics. 
A religion, which shows a man how to lead a vistuous life, how to behave morally under different circumstances slowly elevating himself, and which is the basic concept of religion should mix with politics. Gandhi's dream of 'Ram Rajya' which didnot mean Hindu rajya or anything related to any particular religion but the rajya full of moral and ethical standards.

One of the main things that Gandhi emphasised was that caste had nothing to do with religion. The swadharma concept, of doing one's proper business, set limits to ambition. ${ }^{10}$ Duties and services or seva, together defined a man's place in Society. ${ }^{11}$

But it requires intelligence and discriminating ability to discover one's swadharma. The degraded form of the caste system showed its ugliest face in the form of untouchability.

Gandhi strongly opposed the system of separate communal electorates, in which candidates would seek the support of members of a religious community or caste by competitively espousing their interests against other communities and castes. This system had been introduced in respect of Muslims under the Indian council Act of 1909.

Till the time of his memorandum of May 1928 to the Simon Commission, Ambedkar, too was in favour of territorial constituencies in which all citizens, irrespective of caste or religion, would jointly choose their representatives on the basis of adult franchise.

But, by the time of the Second Round Table Conference convened by the British Government in London in September 1931, Ambedkar had become a proponent of separate electorates for the depressed classes. Gandhi was opposed to this demand. In a speech at the Indian Majlis of Oxford on October 24, 1931 he said : "I am certain that the question of separate electorate for the untouchables is a modern manufacture of a Satanic government. The only thing needed is to put them on the voters' list, and provide for fundamental rights for them in the Constitution... separate electorates will perpetuate the stigma. Do you want the untouchables to remain untouchables for ever?"

Gandhi also said that Ambedkar "has a right even to spit upon me, as every untouchable has, and I would keep on smiling if they did so. But I may inform you that Dr. Ambedkar speaks for that particular part of the country where he comes from. He cannot speak for the rest of India."

When the delegates to the RTC failed. Prime Minister Ramsay McDonald gave his communal award on August 16, 1932. Among its provisions was one that provided for a total of 780 reserved seats for the depressed classes in the provincial legislatures. Of these, 71 seats - "in the areas where these voters chiefly prevail " were to filled by the depressed classes voting as a separate electorate.

Gandhi undertook a fast unto death in protest. The British Prime Minister, while announcing the award, had said that if the communities concerned came to an agreement among themselves, the award would be suitably modified. In view of Gandhi's fast, the caste Hindu and untouchable leaders came up with a compromise formula which was a combination of separate and joint electorates. In the 71 constituencies, where separate electorates were provided for in the award, a primary election would be held in which only the depressed class voters would participate and select a panel of 3 or 4 candidates. These candidates would then stand for election before a joint electorate for the final selection.

Ghandhi not only agreed to the compromise formula but also proposed to apply it to all the 148 seats reserved for the depressed classes. Ambedkar accepted this. The fast was broken and the compromise formula was incorporated in the Government of India Act of $1935 .^{12}$

Gandhi used as strong words as possible to describe untouchability - a blot on the name of Hinduism, a canker, a disease. Since it is a matter which concerns the Hindu community it is no solution if the so called untouchables ran away and became Buddhists as Dr. Ambedkar advised. Each must find salvation within his own community.

Manu describes the vedas, smritifes and characters of virtuous people as the source of dharma. Manu here implies that dharma has to be discovered not only through tradition but also through conscience in determining what is right and what is wrong. But he emphasises that one should not disregard tradition on the basis of merely rational philosophy.

Smrities consist of scriptures like Ramayana, Mahabharata, the Puranas, six systems of philosophy and codes of law. Smriti is man made and hence subject to change. It basically deals with issues like marriage, social organizations and religious ceremonies. ${ }^{13}$

Gandhi having profound knowledge, unlike other leaders tried to spritualise every sphere of human life. Moral bankruptcy is exactly what has led politics to degenerate to the sickening state we find it in today. Thus what Gandhi taught and preached makes a lot more sense now when we can see what a sorry spectacle politics devoid of morality can make of itself.

Gandhi, throughout his life, pursued very secular goals. Early in his career it was the securing of civil rights for Indian settlers in South Africa and from 1915 onwards it was the achieving of Indian national independence. The turning point in his life came in Maritujburg, the capital of Natal, when he was pushed out of 
a train compartment, reserved for whites, in the severe cold of a South African winter. Throughout his life he considered South Africa as 'that God - forsaken continent where I found my God. ${ }^{14}$

Still Gandhi, who laid down his life while upholding secularism, perhaps never used this word in his epic crusades for national unity and communal harmony. Mahatma Gandhi whose most cherished dream of a united India lay shattered, was heart broken but never down hearted in his holy war against communal hatred arid violence. As Mountbatten said, he was his boundary force in the communal massacre in Calcutta. ${ }^{15}$

It is therefore, not strange that the move we have flaunted secularism, the less secular we have become in practice. ${ }^{16}$ At present the country is passing through severe crises, a crisis of identity and an unwarranted of conflicting traditions, on account of it secular nature of Indian polity has come under a direct attack. Undoubtedly the present sorry picture of Indian polity and society for a large extent due to the use of secularism for accomplishing the petty interests by various political parties.

In this context we need a true secular India in which exhibiting secularism and rule of law can be replaced by the spirit of sarva dharma samabhava. Therefore secularism in India means pluralistic philosophy, whose moral basis of sarva dharma sambhava should provide the right atmosphere for building a secular polity through which can be created the actual feeling of nationalism among people.

Whether one agrees or not Gandhi's ideas are surprisingly similar to 'the new consciousness' for which we are groping today. Gandhi had come closer to the problems of our age and solutions to problems which troubled man's minds then and which continue to do so even now. Gandhism is a live and vital doctrine the only condition being its proper understanding and application.

Gandhi tried to spread power in all levels of society. He neither neglected power nor overlooked it but put it in the right place and channelled it in the right direction through the concept of oceanic circles. He repudiated the theory of power (force) moulding an individual in accordance with society as Kautilya, Marx and Mussolini have expressed in their respective theories. Instead Gandhi wanted change first in the inner heart of the individual by following the vows of non stealing, Aparigraha, Brahmacharya and Pallative. According to Gandhi if an individual started following these principles the negative traits such as greed, selfishness would never overpower men and consequently he would work for the betterment of the individual vis avis society.

All in all, he based his observations on his real life experiences, to put an idealist model in front of us, meant to be emulated, it then becomes our decision whether to follow it or not and whether to call his ideas pragmatic, idealistic or existentionalist and so on and so forth.

Thus he was pragmatic in his approach hever forgetting the past, implementing it in the present for a better future, Vivekanda also emphasised the same when he acclaimed, "... let us perfect the means; the end will take care of itself".

Now it is up to mankind to decide, which is at cross roads of history. It may, by outlawing communalism and casteism, choose the part of social progress and high living standards and abolish poverty, ignorance and disease or by failing to take effective steps to outlaw communalism and casteism, continue to face social misery and self destruction.

Today, even at this stage, we all have an opportunity to counter extermism of any kind and to make India stronger and more united with the adoption of a rational and realistic approach helping the poor of both communities by spreading social education, opening new avenues of gainful employment, creating a responsible administration and by encouraging the channels of communication.

A century ago Vivekananda's message to the world at 1893 Chicago parliament of religions is much relevant to India in its. present crises. "The Christian has not to become Hindu or Buddhist, nor a Hindu or Buddhist to become Christian. But each must assimilate the spirit of the other and yet preserve his individuality and grow according to his own law of growth. Every religion has produced men and women of most exalted character. If in the face of this evidence anybody dreams of the exclusive survival of his own religion and destruction of the others, I pity him from the bottom of my heart.

\section{References and Notes}

\begin{tabular}{|c|c|c|}
\hline 1. & Khan Rasheeduddin & 'The Need for Reforms'Hindustan Times, Dec. 12,1993 \\
\hline 2. & Chatterjee M. & 'Gandhis Religios Thouggt'Macmillan Press, Londn, 1983, p. IX \\
\hline 3. & Mahatma Gandhi & 'The Collected Works' Vol. XII Publications Div., Govt. of India, Delhi, 1913, p.94. \\
\hline 4. & Dutta & 'Social, Moral and religious philosophy of Mahatma Gandhi' p. 158 \\
\hline 5. & Iyer RAghavan & Note 121 \\
\hline 6. & Ibid & \\
\hline 7. & Ibid & \\
\hline 8. & Ibid & \\
\hline 9. & Ibid & \\
\hline 10 & Chatterjee, M. & Note 37, P.19. \\
\hline 11. & Ibid & p. 84 \\
\hline 12. & Raghavan G.N.S. & 'To Each His Ambedkar' Hindustan Times, July6, 1994. \\
\hline 13. & Pradhan RamChandra & Review Article to Narahar Kurundkar, 'Manusmriti: Contemporary Thoughts' \\
\hline
\end{tabular}


Importance and Relevance of Gandhian View of Religion and Politics

\begin{tabular}{|l|l|l|}
\hline & & (Translated from the Marathi by Madhukar Deshpande), popular Prakashan, Bombay, 1993 \\
\hline 14. & Chatterjee M. & Note 37, p. 48. \\
\hline 15. & Mishra Shyam N. & 'Secularism: A moment of Truth' Hindustan Times, Feb. 14,1993. \\
\hline 16. & Ibid & \multicolumn{1}{|c|}{ 'A century after Chicago' Hindustan Times Feb. 14,1993. } \\
\hline 17. & Sen Gupta Nitish & \multicolumn{2}{|c|}{} \\
\hline
\end{tabular}

